\title{
Sketches from the history of psychiatry
}

\section{Dorothea Dix: When will we see your like again in Scotland?}

\author{
A. D. T. Robinson, Clinical Scientist, MRC Unit for Epidemiological Studies in \\ Psychiatry, University Department of Psychiatry, Royal Edinburgh Hospital, \\ Morningside Park, Edinburgh
}

Community care around Edinburgh was very poor during the early 1850 s. Insane paupers were often detained without warrant in poorhouses and private houses, with no official visits from the sheriff and no records of care kept. Accommodation was often bad, with scant furnishing, such that inmates might have to eat their meals off their knees. Where patients had dirty habits conditions were described as "very close and unpleasant". Those who received a wash were those who were noisy or violent, using water that was likely to be cold. Only in the summer might a patient be allowed to bathe in the sea. Sexes were often imperfectly separated though restraints might be used, for example, to a bedstead at night. In some establishments, females might fare better in terms of clothing and food (Scottish Lunacy Commission 1857).

This state of affairs had not passed unrecognised. In introducing two bills for reform of English and Welsh lunacy legislation, Lord Ashley said, "I believe that not any country in Europe, nor in any part of America, is there any place in which pauper lunatics are in such suffering and degraded state as those in her Majesty's kingdom of Scotland" (Tuke, 1882 , p. 185). A bill had been proposed in 1818 for Scotland to allow the erection of district lunatic asylums. The revenue would have come from the rates, however, and the bill was obstructed. The Lord Advocate (Lord Rutherford), the Home Secretary (Sir George Grey) and the Secretary of War introduced a "good bill" in 1848, designed to amend the law, particularly in regard to the care and custody of the insane and to establish asylums for pauper lunatics. It had to be withdrawn following petitions from almost every shire in Scotland. Reintroduction in 1949 met the same opposition and suffered the same fate.

The role of Dorothea Dix in Scottish legislation reform was entirely fortuitous. Henderson wrote (1964) that "her accomplishments in the United States and London (that is her philanthropic work in the provision of adequate care and treatment for the mentally afflicted) would have allowed her to rest on her laurels" when she arrived in England in 1854. She was described as being discouraged in both body and mind at that time, coming for rest (Cheney, 1943-44). The reason for this state of health was the final veto by President Pierce of a bill to secure permanent federal aid for American lunatics, a project she had worked on for nine years.

Not long after her arrival in England she went to stay with Dr Hack Tuke. He describes that it was while she was his guest at York that she determined to ascertain the conditions of the insane in Scotland. This followed discussion with him, as he knew that while the chartered asylums were famed yet a great mass of poor lunatics might be "altogether neglected and shamefully treated" (Tiffany, 1890). Less than a fortnight after her arrival in England she wrote of her plans to visit Scotland to see the hospitals there. However, her friends persuaded her to tour Ireland first (Marshall, 1937).

In February 1855 Miss Dix wrote from Edinburgh to her confidante in America, Miss Anne Heath, of "hundreds of miserable creatures ... looking for release from a bitter bondage which the people at large are quite unconscious of' (Tiffany, 1890, p. 231). The account of her first visit to Scotland by Bucknill (1856) was described as follows; "In making a tour of Europe, she came to England and thence to Scotland; visiting con amore, the different asylums in her way both public and private. When she came to Gartnaval she was instantly made perfectly welcome to see all over the Glasgow asylum as a matter of course. But into some of the private asylums kept for pauper lunatics, near Edinburgh, she was not permitted to enter".

This initial foray into Scotland was not attended by authorisation from the Home Secretary, thus although she found matters to be awry in Musselburgh, she was obstructed in her wish to visit the paupers' residences at the dead of night, when she 
would not have been expected. The Lord Advocate was reported to feel a difficulty at giving such permission to a non-official person (Tuke, 1882). She discussed this obstruction with her supporters and felt she should approach the Home Secretary. When the Lord Provost of Edinburgh believed she was going to act in this way, he became alarmed and decided to forestall her. However, he stopped first to have his trunk packed prior to the trip to London. This allowed Miss Dix to board the night train with only her carpet-bag, thus stealing a march on him. [No doubt she sat up for the journey, as she loathed sleepers (Marshall 1937)]. Miss Dix wrote a long account of her adventure to a friend in Boston, Massachusetts on 8 March 1855:

"While in Edinburgh I had discovered eleven Private Establishments for the Insane, to which licenses had been given by the sheriff of Mid-Lothian without regard to the special qualifications requisite. People of the lowest grade of character and very ignorant, had been accepted upon their application for liberty to open houses for all classes of patients.

... Those at Musselburgh, six miles from Edinburgh, were so very ill-ordered and the proprietors so irresponsible for all they did, or did not do, that I took decisive steps...

The sheriff, when I appealed to him as really the sole authority, trifled, jested and prevaricated. I could not excuse this. The weather is very cold, the poor patients by hundreds suffering ...

The conclusion was that nothing would do but to demand of the Home Secretary, Sir George Gray, in London a Commission for Investigation. But who was to go? I looked into my purse and counted time, considered my health, ... but my conscience told me quite distinctly what was my duty...

I first telegraphed to Lord Shaftesbury, asking for an interview at three p.m. the following day" (Tiffany, 1890).

Her letter continues by describing her visit to the Duke of Argyll in order to get his patronage to petition the Home Secretary. She saw Lord Shaftesbury who had arranged a meeting of the Board. Initially she did not see the Home Secretary in person but two days after her arrival felt that a meeting was necessary in order to expedite proceedings. However, he doubted whether he had the power to issue warrants for a Scottish Commission without the compliance of the Lord Advocate. The Lord Advocate was summoned to London and was expected on the Monday. In the meantime Miss Dix proceeded to see Sir James Clark, the Queen's physician, who "entered cordially" into her plans. She had to wait until Thursday for the arrival of the Lord Advocate but by the Friday had obtained the promise of a Commission of reform for all Scotland.

In fact, within this two week period Miss Dix achieved two commissions. The second was an inves- tigation of the care of the insane in Mid-Lothian. The Royal Commission into all Scotland was appointed on 3 April 1855, "to inquire into the condition of lunatic asylums in Scotland, and the existing state of the law of that country in reference to lunatics and lunatic asylums." On 9 June 1857 a bill was brought in by the Lord Advocate "to alter and amend the laws respecting lunatics in Scotland". It contained 114 sections, with the chief provisions related to providing a Board of Commissioners who had clearly defined duties, the subjecting of Scottish asylums to the law, the duties of the sheriff in visiting and inspecting asylums and an improvement in the medical information for creating asylums where necessary, and a procedure for dealing with forensic patients was defined.

Miss Dix contributed to the Commission of Enquiry and an impression of her is conveyed by $\mathrm{Dr}$ J. Browne, the son of W. A. F. Browne who was the Superintendant at Crichton Royal, and he called her the "American Invader". [She was also called an "interfering busybody".] "When at home on holiday in 1855 , I had the privilege of meeting the celebrated American philanthropist Miss Dix, who was then on her self-imposed tour of investigation - authorised, however, by the Home Secretary - as to the conditions of lunatics in Scotland, and who was my father's guest for two days, as she studied the state of matters in the Crichton Royal Institution. I remember overhearing at table Miss Dix's warmly approbatory remarks on much that she saw in the Crichton Royal Institution of those days and her inquiries as to the composition of some distinctly Scottish dishes, such as kail, shortbread, scones, oatcakes and haggis" (Easterbrook, 1940, p. 5-6). Also she must have appreciated the qualities of tartan in keeping out the cold, as a letter was found written later in her life, asking for use of a shawl she had bought in Edinburgh and given to a friend (Marshall, 1937).

The happy conclusions to her endeavours on behalf of pauper lunatics suggests that, at times, an individual may act as a catalyst in provoking the government to act or public opinion to change. It is right for the medical profession to highlight instances where there is governmental delayed response, such as to the Griffith's report on community care (Murphy, 1988). There is a dearth of information the development of services away from the hospitals in Scotland but what is known suggests the picture is bleak (McCreadie et al, 1985). Community care in England and Wales for the mentally ill and handicapped has had its problems highlighted (National Consumer Council, 1987) and the problems of the mentally abnormal offender in England is well recognised but with no improvement (Bluglass, 1988). The response to a major health crisis both from the public and government only after an event of public interest and 
personal concern to the President, suggests that pressure from concerned professionals alone is not always sufficient (Shilts, 1987). Thus it is imperative to keep an open mind on the ways and means to influence both goverment and the public. Scotland may yet need the services of more of the ilk of Miss Dix.

\section{Acknowledgements}

I acknowledge the help of Professor Kreitman and of Dr Barfoot and Mrs Williams with gratitude.

\section{References}

BLUGLASS, R. (1988) Mentally disordered prisoners: reports but no improvements. British Medical Journal, 296, 1757-1758.

BuCKNILL, J. C. (1856) Report of the Irish, Scotch and American asylums during the past year. Asylum Journal of Mental Science, II, 423-424.
Cheney, C. O. (1943-44) Dorothea Lynde Dix. American Journal of Psychiatry, 100, 61-68.

Easterbrook, C. C. (1940) The Chronicle of the Crichton Royal. Dumfries: Courier Press.

MCCreadie, R. G., AfFleck, J. W. \& Robinson, A. D. (1985) The Scottish survey of psychiatric rehabilitation and Support Services. British Journal of Psychiatry, 147, 289-294.

Marshall, H. (1937) Dorothea Dix, Forgotten Samaritan. North Carolina: University of North Carolina Press.

National CONSUMer COUNCIL AND tHe Association OF COMmunity Health Councils for ENgland AND WALES. (1987) Care in the Community. Report, December, 30-35.

SCOTtish LunaCY Commission (1957) Appendix to the Report. Edinburgh: Thomas Constable.

SHILTS, R. (1988) And the Band Played On. Harmondsworth: Penguin Books.

Tiffany, F. (1892) Life of Dorothea Lynde Dix. Cambridge Mass.: Houghton, Mifflin.

TUKE, D. H. (1882) Chapter in The History of the Insane in the British Isles. London: Kegan Paul, Trench.

Psychiatric Bulletin (1989), 13, 307-308

\section{Review}

Power in Strange Places: User Empowerment in Mental Health Services. Edited by Ingrid Barker and Edward Peck. Good Practices in Mental Health, 380-384 Harrow Road, London W9 2HU. 1988. Pp 30.

\section{Arming the weak: the growth of patient power in psychiatry}

The word "consumerism", despite its somewhat slimy connotation, has become fashionable as the principles of the market economy take hold in most developed countries. It describes the power and influence of the buyer or consumer; no longer a passive recipient of goods and services but now representative of a powerful lobby that can topple major corporations as the campaigns of Ralph Nader in the United States have shown.

The transfer of consumerism to psychiatry, although perhaps inevitable, has been delayed because of the unusual position of the psychiatric patient. Most patients are not consumers in the market sense; they have little wish to buy mental health services and some go to extraordinary lengths to avoid them. Those who are regarded as in greatest need reject them absolutely and have to be forced to become consumers through the process of law. Thus, in the words of a member of the Campaign against Psychiatric Oppression, "survivors of the mental health system are no more consumers of mental health services than cockroaches are consumers of Rentokil". Yet this obvious imbalance in distribution of power between consumers and providers is one of the main forces behind the growth of the consumer movement in psychiatry. In this booklet, Ingrid Barker and Edward Peck have brought together accounts of the first steps towards user empowerment in psychiatry. They regard this as "the most crucial issue in mental health services", as "people who have been devalued and disempowered can only start to be restored to full citizenship if the power imbalance between users and providers is redressed". They realise that a transfer of power from the service providers to the service users is likely to be resisted at first, but hope that when the professionals have had a chance to read about, observe and experience the new movement they will be converted to its philosophy.

The blueprint for many of the developments in the United Kingdom has been established in Holland. The Dutch are very reasonable people and like to consult with each other to get mutual agreement wherever possible. Therefore it might be expected that psychiatric patients would be involved in this process earlier than in many other countries. In 1981 the Patients' Advocates Foundation (PBP) was set up to represent the interests of psychiatric patients. The advocate assists patients who complain and can have access to full medical records, provide information to patients about their legal rights and is 